\title{
Russia between Europe and Asia
}

\section{An Empire with Uncertain Boundaries}

The transcontinental location of the Russian state is a constant factor throughout its history. It fostered a multiplicity of religious, cultural and institutional relations, largely spontaneous and pluridirectional, and not necessarily implying a clear dichotomy between East and West. After all, Europe and Asia meant different things in different centuries. Like a sponge, Russia absorbed its military vocabulary from German and the word chay for tea - the second most popular national drink - from Mandarin Chinese. This intermediate position affected the evolution of its borders, but also influenced representations of national identity and the ideology of the state. In the sixteenth century the Tsardom of Russia began its eastward expansion by conquering the Tatar states of Kazan and Astrakhan, and to some extent it inherited the legacy of Mongol rule. It consolidated its power in the West, resisting the interference of the Polish-Lithuanian Commonwealth, a more prestigious and powerful state at the time. The Tsar would also, after the partitions of Poland in the eighteenth century, claim the title of King of Poland. The centuries-old process of territorial expansion, directed towards different regions of Europe and Asia at different times, encountered its main setbacks during periods of profound political, social and economic crisis, accompanied by significant losses of territory and by discontinuities in dynasties and in the form of the state. This happened during the Time of Troubles (1598-1613) and the cycle of world war-revolution-civil war of 1914-1921, as well as in the historical phase that began with the collapse of the Soviet Union in 1991 and the birth of the post-Soviet states.

Identification with European forms of state and ideologies became an important issue when Russia came into contact with the political structure and modernity of eighteenth-century Europe, at the time of the wars and reforms of Peter the Great. The question of Russia's Europeanness depended not only on an intensifying of relations, which had already begun in the seventeenth century, but also on the fact that in the eighteenth century the European states were changing in nature and expressing a greater awareness of their superiority to the rest of the world. The ambition to play a far more influential international role, symbolised by the assumption of the new title of imperator (a foreign word), began a long period characterised by the reception of ideas provided by the European context in the ensuing historical phases, ideas as diverse as the philosophy of the Enlightenment, modern nationalism and socialism. These intellectual influences were 
reinterpreted according to the prevailing circumstances of each period. They were used to affirm the legitimacy of the state and define the borders of its sovereignty, borders established or imagined as a purpose of political action.

It would be misleading, however, to judge the Russian oscillation between East and West, from the eighteenth century to the twentieth century, by the measure of greater or lesser Europeanisation. This point of view implicitly presupposes a teacher-pupil relationship, a perpetual apprenticeship with respect to which historiography could only measure progress and lacunae with reference to a given model. On the contrary - and this is the first point that must be emphasised - the ideology of the Tsarist monarchy, its nineteenth-century revolutionary antitheses and later the Soviet project (both geopolitical and ideological) expressed at different times a complex reception of European and extra-European models always combined with the ambition to be an autonomous driving force - that is, to be the centre, not a peripheral area, of the world. In different ways, these variations in the idea of the state expressed the desire to overcome the contrast between East and West, between Europe and Asia. They were animated by the desire to constitute a point of political and cultural irradiation, expressed in a universalistic or internationalist vocabulary, in accordance with the circumstances of the different periods.

This projection was accompanied by a second, fundamental continuity that of the contrast between the grand aims and the limited means available with respect to the conditions of each historical age. The state which imagined itself in the fifteenth century as the "Third Rome" - the direct heir, without any need for European legitimisation - of the most prestigious empire in history taken into consideration at the time, was a small eastern Slavic principality. Down the centuries, expansion over a boundless space became a founding myth of the monarchy. The widening of state boundaries took on the significance of a symbolic sanction of the sovereign's majesty and later of national greatness, but made it difficult to govern extremely heterogeneous populations and to mobilise the resources of remote regions. Despite the consolidation of the bureaucracy during the nineteenth century, the state was governed by a still relatively thin and rarefied administrative apparatus, which, even in the Soviet era, aroused the fear of losing control over territories that were difficult to guard and defend. The geological and climatic conditions hindered the development of a productive agriculture. At the times of greatest international power, when its troops paraded in Paris and Berlin after the Napoleonic wars and the Second World War, Russia's economy was inferior to that of the enemies it had defeated, even though in the military and especially the cultural field the gap was much narrower.

This tension between universal ambitions and limited resources did not preclude the territorial, economic and political growth of a state which, in the 
mid-twentieth century, would emerge on the international scene as one of the two world superpowers, but it did affect its historical development. It generated both geopolitical insecurity and a tendency on the part of the elite to mirror themselves and seek legitimacy in the most prestigious models of every age, and not necessarily only European ones. The disparity between the means available and the ends aspired to prompted the nineteenth-century debate about the gap between Russia and more advanced societies, the urgency of Stalinian modernisation and later the Krushchevian slogan of "catching up with and overtaking" the United States after the Second World War. Truly self-confident Empires, like the Chinese or British empires at the height of their power, would never have represented themselves through a comparison with a more advanced state. Expansionist ambitions and difficulties in controlling the peripheries conferred a particular value on territorial integrity - the quest for an unalterable boundary - but at the same time also produced its contrary: a perpetual indeterminacy of the outer limit. Russia always had to its east, south and west ambiguous okrainy, or regions "close to the border" and of uncertain status, lands that were "other" but perceived as "its own", which it could imagine itself incorporating by annexation, or, preferably, by spontaneous, enthusiastic adhesion.

\section{A European Power in the Age of the Enlightenment?}

It was Vasily Tatishchev, an intellectual and geographer close to Peter the Great, who "discovered" and selected the Urals as a boundary between Europe and Asia which ran across the Empire in its interior, continuing, with a more controversial uncertainty, towards the Caspian Sea. The new line replaced the previous one represented by the River Don, which had put a large part of modern European Russia in "Asia", and which until the end of the seventeenth century had not aroused any particular debate or interest. When Russia expanded eastwards, after defeating the Swedes in the Great Northern War (1721), geographers felt the need to widen its European demarcation and distinguish it more clearly, not only in a geographical but in a cultural sense, from Asian possessions inhabited by "savages" or subjects "of different faith" (inovertsy). To say that the Empire was divided into two parts, a European one and an Asian one, constituted a claim to the status of a European power endowed with vast extra-European possessions, like Britain, Spain or Portugal at that time. A capital built from scratch according to Baroque architectural models could be seen as the metropolitan centre of an imperial state which projected its expansionist ambitions right into the Far East. 
In this way the geographical explorations ordered by Peter the Great discovered the north Pacific and the coasts of North America (later the tsars' Alaska), which until the end of the eighteenth century were regarded as an extension of Russian possessions in Asia, an offshoot of the East.

When Catherine II stated peremptorily that "Russia is a European power", she was simply recording a fact - the significant role that the Tsarist Empire had taken in the military and diplomatic game during the Seven Years' War. Her most important political document, the Nakaz, or "Instruction", of 1767, described a model of the state which drew copiously on the texts of the Enlightenment. Yet the borrowing also involved some notable semantic shifts. Whereas Montesquieu had described the form of government of a large state as a predominantly oriental "despotism", the Empress corrected him and translated "autocratic power" (art. 10 of the Nakaz), to highlight not only the respectability of her sources of legitimisation, but also the continuity with the original meaning of the term "autocrat" a sovereign who is no one else's vassal. The reception ignored the principle of the separation of powers which is central to L'esprit des lois. Admittedly, it borrowed from Montesquieu the concept of intermediate bodies - the heritage of ancient aristocratic autonomies which were supposed to limit power in a well-ordered monarchy. But the model of the state sketched out by Catherine did not apply this definition to those institutions of the Tsarist state which could most plausibly have been compared to estate bodies possessing autonomous rights, such as the Boyar Duma, which had been suppressed in 1707. The term "intermediate powers" was used of the Senate and the magistratures of the "regular state" created by Peter I (Nakaz, art. 18, 20) - that is, they were considered to be administrative institutions, rather than political bodies distinct from the executive power. Thus Montesquieu's concept took on a meaning which was the opposite of the original one: sectors of the absolute state which were responsible for the implementation of imperial will, rather than for its limitation by law.

The "Greek project" of the conquest of Constantinople formulated during the Russo-Turkish wars of 1768-1774 and 1787-1892, a theme magisterially explored by Andrey Zorin, reveals the profound and ambiguous link between the Tsarist reception of European Enlightenment and the expansion of imperial boundaries. The theme also shows the difficulty of placing this reception on the horizontal axis of progressive Europeanisation, along an ideal itinerary which proceeded unequivocally from west to east. The new territorial acquisitions were much more than strategic objectives, such as the consolidation of a Black Sea harbour and therefore of access to the Mediterranean. The Greek project was one of the grandest, most detailed and most ambitious foreign policy plans ever conceived by the Russian state. It was accompanied by a carefully constructed and supervised symbolic system. After taking the "city lost by the Greeks" and defeating 
the Ottoman Empire, the Romanov state would have to split up into two allied empires, the northern one of Petersburg and the southern one of Constantinople. The thrones of these two Russian states would be occupied by Catherine's grandsons, Alexander and Konstantin, whose names were ostentatious allusions to the deeds of Constantine the Great and Alexander the Great. The shift in the boundaries would have to proceed southwards and then ideally towards Persia, according to the expansionist plan of the great Hellenistic states. Also envisaged was the taking of Jerusalem - the cradle of Christian Russia - and Ethiopia.

Catherine and her favourite Grigory Potëmkin were genuinely convinced that all this would represent a return to Russia's Hellenic and "Athenian” roots. Their Athens was a political symbol cleansed of its republican connotations and ambiguously superimposed on the conquering spirit of Alexander the Great; their Greece was a nation of philosophers seen as a reinforcement and completion of Christian Byzantium, not an antithesis to it. There was a subtle but significant difference between this expansionist conception and the Euro-centric arguments with which Voltaire urged Catherine to combat barbarism, to make war on the "enemies of the arts and the oppressors of women" in order to free the peoples from the oriental despotism of the sultan and the superstition of Islam. Rather, occupying or liberating Constantinople meant a return to the sources of the civilisation from which European reason had originated, sources that the Empire claimed as its own. This grand perspective - a state utopia inextricably linked to expansionist Realpolitik - turned on its head the genealogy whereby the sources of reason had historically migrated from Athens to Rome, from there to Paris and then to Petersburg, the capital of a tabula rasa on the north-eastern margins of Europe, in the image suggested by Leibniz. On the contrary, returning to its ideaplace of origin, Russia claimed direct descent from the cradle of European civilisation. The Tsarist empire came to think of itself as the most authentic interpreter of the "lights of reason", not as a pupil of European philosophers: the Russians descended from the Greeks, and as such represented not the periphery but the core of the eighteenth-century Enlightenment.

Therefore the New Russia of the southern steppes and the Crimean peninsula, the partial result of a macroscopic disparity between visionary ambitions and military reality, assumed already at that time an intense ideological importance, going far beyond justificatory propaganda or public relationships between crowned heads. These new Russian (though in reality Tatar or Greek) regions did not represent only territories first occupied and then populated in the first half of the nineteenth century out of a desire for conquest or economic interest. They had to be symbolically designated with Greek toponyms, such as the governorate of Tauris and Odessa, the city of Odysseus. Crimea had to offer the scenario of a garden planned by reason, an earthly paradise where not only 'Russians' (the 
Empress was a converted German princess) but all populations lived harmoniously together under the sceptre of ruling Minerva. Vasily Petrov's Ode to Potëmkin (1778) listed without qualitative distinctions "the East and the West, the North and the South", as well as "the Moldavian, the Armenian, the Indian or the Greek, or the black Ethiopian”. The Crimea occupied a central position in this political geography as a mirror of imperial greatness, living proof of an Enlightenment concretely realised by the Tsarist Empire.

\section{Russia and Europe in the Age of Revolutions}

The nineteenth-century debate between proponents and adversaries of the European nature of Russia, only superficially described as a contest between "Slavophiles" and "Westernisers", was to some extent influenced by the different sensibility of the Romantic age, with its characteristic desire to define the identity of peoples and their historical destinies. Romantic culture attempted to trace the differences between major civilisations and their real or supposed underlying principles, such as the characteristics that distinguished the Slavic from the Romano-Germanic world. The admirers and detractors of an abstract, stylised Europe argued among themselves on the basis of the philosophical categories of Schelling and Hegel or employed the historiographical arguments of Guizot and Tocqueville - proof that they did in fact belong to the European intellectual context. The historical and philosophical debate about the antithesis between Russia and Europe was contemporaneous with the emergence of a new national ideology of the monarchy, the so-called "official nationality" summed up in the triad Orthodoxy, Autocracy and Nationality. These parallel developments were part of a search for a response to the new ideas about citizenship and popular sovereignty that had arisen from the revolutions of the late eighteenth century. They were a reaction to a political context which in the meantime had changed profoundly and no longer corresponded to that of enlightened absolutism.

The Russian reception came rather late. In the early years of his reign (18011825), Alexander I availed himself of the help of a Francophile statesman with radical ideas, Mikhail Speransky, and still imagined himself and his young friends of the Secret Committee as "Jacobins on the throne", in continuity with the idea of an Empire intent on realising the most innovative European ideas. Even after 1815 the concert of Europe in the restoration period and the ideology of the Holy Alliance enabled the Tsar to present himself as a monarch allied with the other European sovereigns of the time, in harmony with the King of Prussia and the Habsburg Emperor. The crisis of the paradigm of Russia as a European power 
was triggered by three events which occurred in a short period of time, from 1825 to 1830 . The first was the Decembrist uprising of 14 December 1825, which forced Nicholas I (1825-1855) to ascend the throne with the anxiety of a sovereign who had just put down a Risorgimento-like insurrection. The threat had developed in the centre of the state, among the young officers of the regiments of the Imperial Guard stationed a short distance away from the Winter Palace. The second event was the Polish Revolution of 1830-1831, which took place in the most prestigious of the peripheral regions that had been annexed during the eighteenth-century period of expansion. Congress Poland had hitherto enjoyed the highest degree of autonomy that the Tsarist autocracy was prepared to grant to a province, to the point of tolerating the paradox of an aristocratic constitution in the years when Russian political thought, starting with Nikolay Karamzin's Memoir on Ancient and Modern Russia (1812), was beginning to associate the national identity with autocratic prerogatives. The third event also took place in 1830, but outside the boundaries of the state, in France, the cradle of the Enlightenment. The July Revolution shook the post-Napoleonic status quo and initiated a historical period in which Europe would appear in Russia, to intellectuals and sovereigns alike, in the guise of the two most important ideologies of its long nineteenth century: socialism and nationalism. The three events anticipated tendencies that would continue in western Europe, as well as in the centre of the Empire and on its periphery, as evinced in the pan-European revolution of 1848, the second Polish revolution of 1863 and the long period of the Russian revolutionary movement, which began to challenge the Tsarist state in 1859-1861. This phase of re-elaboration in the years 1825-1855 corresponded to a period of relative peace, when the impulse towards expansion was attenuated. The long Caucasian conflict may be interpreted as a defensive reinforcement of the southern border. It accompanied an attempt to consolidate the state and its institutions internally, from legislative codification to the reinforcement of bureaucracy.

The concept of Russian otherness with respect to Europe took shape in response to the demands of these real or perceived challenges. The despairing conclusion with which Pëtr Chaadayev noted the absence of an autochthonous Russian culture in the first of his Philosophical Letters (1836) appeared contemporaneously with the dismay with which Sergey Uvarov expounded for the first time, in a letter to Nicholas I in March 1832, the doctrine of official nationality. Uvarov spoke of "events of enormous importance" which had had "a baleful influence on the development of culture in our homeland", undermined the confidence of those who believed in "progress" and in the "future of the peoples", compelling Russians "to doubt ourselves”. This premise supported the argument for the project of a "national and popular religion" (narodnaya religiya) to be inculcated from above, through the expansion of university education. The new 
official ideology was meant to give cohesion and a sense of collective identity to the subjects of a state which appeared dangerously "shaken in its political, moral and religious foundations".

The first authors to contrast Russia and Europe as civilisations based on qualitatively opposite principles were the theorists of this post-Enlightenment and post-Revolutionary monarchic ideology. In his Historical Aphorisms (1827) the court historian Mikhail Pogodin starkly contrasted a Europe which had grown through the logic of "conquest" and "revolution" with a Russian state genetically characterised by the different and superior principle of "voluntary submission" to power. The presupposition behind this official nationalism was a deeply pessimistic vision of Russian society - the idea of a "magnificent Russian people, but one that is still magnificent only in power" because "in practice it is vile, uncontrollable, brutish" without the disciplining power of autocracy.

The debate between the intellectuals, though limited to small circles devoid of political influence, arose in response to these stimuli. The Westernisers asserted the European nature of Russia to substantiate hopes of reform. Russia was an essentially European country, which had been temporarily diverted or obstructed in its development by certain historical factors: the retarding interval of the Mongol yoke or - according to the historico-geographical interpretation of Sergey Solovëv - the vastness of immense and not easily defensible spaces, which had slowed down the penetration of western civilisation and favoured the formation of a centralised and militarised power. Hegelian logic made it possible to reinterpret eighteenth-century absolutism, from Peter the Great onwards, as an intermediate phase in the historical dialectic, the precondition for a subsequent affirmation of conscious reason and law. Westernising historians such as Konstantin Kavelin would interpret the liberation of the peasants in 1861 as the next step in a sequence of emancipations from above which had begun with the abolition of compulsory state service for the nobility by Peter III in 1762, and which was to be followed by political and constitutional rights. The Europeanising perspective, however, did not guarantee a liberal or democratic outcome. In Westernisers such as the historian and jurist Boris Chicherin it translated into a different kind of support for autocratic prerogatives, summed up in the formula "strong power and liberal measures", only the first in a long series of metaphors subsequently used to legitimise the model of an authoritarian modernisation.

The alternative view of the Slavophiles did not question the principle of autocracy, which they accepted as the natural form of government for Russia. However, in their effort to emphasise the dignity of national culture with respect to western European culture they substantially modified the concept of "the Russian people”. Unlike apologists of the monarchy such as Pogodin or Egor Kankrin, who had seriously suggested calling the state "Petrovia" to emphasise 
that the nation was a direct creation of the Tsar's, the Slavophiles stressed the existence of a culturally autonomous pre-Petrine society. They retrospectively constructed a national tradition identified with a religious civilisation, rather than with the person of the sovereign. The Slavophiles opposed any social-contract definition of the state. They rejected an artificially imposed "Petersburgian" rationality and contrasted it with the "Muscovite" concept of a people seen as an inherently harmonious, choral, Orthodox Christian world, a society capable of expressing values independent of the disciplining education of the Empire. The fiery Slavophile polemic did not necessarily express a rejection of modern industrial society. Aleksey Khomyakov appeared at the Great Exhibition of 1851 in London, a showcase for and celebration of positivist progress, with a project for a steam engine; and many Muscovite entrepreneurs of the mid-nineteenth century would also be Slavophiles. This vision fomented the view of a Russian people that was far from antimonarchical and yet neither "uncontrollable" nor "brutish", rather a collective entity capable of creativity and territorial expansion.

The Russian socialism founded by Alexander Herzen, which would become the antithesis of Tsarist monarchy, also originated as a response to the social and national revolutions of Europe, in this case through critical reflection on the events of 1848. He modified the Slavophile concept of an "Orthodox people" in an ethical and social direction. In the German writings of the Prussian conservative August Haxthausen he discovered the Russian peasant commune or obshchina, the model for the future state based on federal autonomy and on the democratic management of collective resources. After emigrating to London, Herzen often wrote in French for a cosmopolitan emigré readership. His socialism took on the meaning of a national ideology with messianic tones. It was a reply to those who spoke of the insignificance or inferiority of Russian civilisation and at the same time a declaration of faith in Russia's destiny of carrying a message of universal liberation. The Russians appeared capable, in the future, of overcoming the failed outcome of the revolution of Europe, "a decrepit old world", contrasted with the "savage, fresh energy ... of new peoples" (as he writes in Epilogue of 1848, published in 1849).

In the first revolutionary proclamation To the Younger Generation, circulated anonymously at the University of Petersburg in autumn 1861, Michail Mikhailov and Nikolay Shelgunov contrasted a metaphor for conformist European mediocrity ("little German gardens and woods") with the Russian determination to "divide our field ... as land was divided in antiquity, when there was room for everyone" - that is, in the ager publicus of the Roman republic. This variant of the idea of direct descent from classical greatness was often accompanied by a comparison with the youthful extra-European freshness of the United States. The Russian debate autonomously developed Tocqueville's parallel between Russia 
and America as peoples of the future. In his article La Russie (1849), in which he assessed the European revolution and delineated the populist political project, Herzen quoted Goethe's famous line Amerika, du hast es besser, and added immediately afterwards that this definition s'applique fort bien à la Russie.

\section{European Colonialism or Eurasian Empire?}

Autocratic ideology and westernising reformism, nationalism and socialism intersected with further expansion towards the east during the second half of the nineteenth century. Defeat in the Crimean War (1853-1856) intensified the awareness of needing to make up ground, and prompted a long period of reformist projects. During the same years the Tsarist state completed the pacification of Transcaucasia, annexed the vast regions of Ussuri and Amur in the Far East (1860) and penetrated into central Asia (1865). Although the Congress of Berlin (1878) thwarted its ambitions of Pan-Slavic and Balkan hegemony, in the east the Russian troops took control of Turkestan, with the protectorates of Samarkand and Bukhara (1885), reaching the edge of the territory conquered by Britain in Afghanistan. After the Boxer Rising in China (1900), the Tsarist Empire occupied part of Manchuria, while other expansionist projects during the First World War would target northern Persia, the southern coasts of the Black Sea and the Bosphorus. To what extent could these territorial acquisitions be described as the work of a great European state determined to participate in the conquest of extra-European colonies?

The geography of the annexed regions - beyond the Caucasus Mountains and the Hungry Steppe - made the identification with western colonialism to a certain extent plausible, and in many respects flattering. Functionaries and orientalists carefully studied the ways in which the French governed Muslim Algeria and the British had dealt with the Sepoy Mutiny in India. Just as the Slavophiles had discovered nationalism through Schelling, so the knowledge of the Russian East developed through the intellectual mediation of Carl Ritter's Erdkunde, published in Russian translation from 1856 onwards. European colonial literature, for example De la colonisation chez les peuples modernes by P.-P. Leroy-Beaulieu, published in 1874 (and in Russian translation in 1877), provided classifications useful for interpreting the recent acquisitions. The patriotic fervour that had inspired the emancipation of the serfs in 1861, a "scandalous" residue which prevented Russia from considering itself a modern and hence completely European nation, at the same time fostered the vision of a great civilising mission towards 
the East. After all, in the mid-nineteenth century every European power worthy of the name had, or was trying to acquire, colonies.

Nevertheless, Tsarist culture was always reluctant to adopt the colonial paradigm in its entirety. The history of European colonialism presented numerous secessionist movements which had met with varying degrees of success, from the increasing autonomy of the British dominions to independence movements in Latin America, not to mention the exemplary case of the American Revolution. The perspective of a Russian destiny in Asia developed at a time when the risk of secession was materialising in the Polish revolt of 1863 and in the contemporaneous Siberian autonomist movement. The awareness of a very limited capacity for governing the territory (in the mid-nineteenth century it was easier, starting from Petersburg, to reach New York than Vladivostok) was accompanied by an almost obsessive concern for the integrity of the state territory seen as a dynastic heritage. The autocratic principle inhibited the adoption of a metropolis-colony hierarchy which might foreshadow, albeit implicitly, future political fragmentation and the devolution of sovereignty. So it seemed inadvisable to describe Turkestan or the Amur region as Asian colonies. "We have no colonies", the Interior Minister declared peremptorily in the mid-1880s. The official language referred rather to an "incessant expansion of the Imperial Russian state" (in every direction) followed by the gradual "assimilation of regions near the border".

From the 1860s to Stolypin's reforms in the years 1906-1911 important sectors of the bureaucracy set themselves the task of overcoming the separateness of the peripheries in order to promote the cohesion of the state. They pursued in a wavering manner, and with uneven results, policies of demographic, linguistic and institutional assimilation, trying, for example, to replace the viceroyal authority of peripheral governors-general - a legal token of a state of temporary otherness - with administrative regions more similar to those of the European Russian centre. In the more enlightened exponents, such as the Finance Minister Nikolay Bunge, Asian policy was understood less as a Russification of territorial conquests than as the construction of a nation-empire through a process of mutual integration between Russians and non-Russians, on the basis of common laws and institutions. At the beginning of the twentieth century the idea that the hub of the state was shifting eastwards was already widespread. In 1905 an official commission chaired by Dmitry Mendeleyev calculated the "demographic centre" and the "geographical centre" of Russia, suggesting that the former, located near Tambov, south of Moscow, was destined to move progressively until it coincided with the latter, north of Omsk, in western Siberia.

Unofficial culture reinforced these views and began to blur the meaning of a cultural difference between European Russia and Asia. As late as 1893, Pëtr Semenov-Tyan Shansky described Russian colonisation as a "shifting of the eth- 
nographic boundary of Europe towards the east”, but this Westernising view was contested in many circles. Authors of different ideological persuasions challenged the parallel between the Tsarist conquests and European colonial expansion. In Russia and Europe (1869) Nikolay Danilevsky questioned the hitherto dominant eighteenth-century distinction between a European part and an Asian part of the state. He turned Tatishchev's Petrine geography on its head and denied the significance of the Urals as a boundary between continents. In this perspective Russia became the centre of a terrestrial mass, a unitary "natural region" with respect to which western Europe was reduced to the status of a promontory of Asia. Considered in this light, the eastward advance lost the character of a Europeanising conquest of foreign lands and became a natural, ambiguously internal process. Vladimir Lamansky systematised this view further in Three Worlds of the Eurasian Continent (1892), in which he argued for the existence of an intermediate Russian world radically distinct from both Europe and Asia, a single "homeland" which extended uninterruptedly eastwards too and was subject to a process of reappropriation rather than of external occupation. Socialist authors such as Sergey Yuzhakov developed the populist idea of the peasant as a vector of Russianness and analysed Russian penetration into the East on the basis of a "popular", communitarian principle, in contrast to British capitalist imperialism. The orientalist Esper Ukhtomsky, who was closely associated with Tsar Nicholas II, went further and argued for the Mongol origin of the Empire: the Tsar did not descend from Byzantium but from Genghis Khan, so Russia was bonded to the peoples of the East by the traits of cultural affinity, peaceful coexistence and respect for local traditions. Unlike the European states, which were anxious to plunder China, the Tsarist Empire acted on the world stage as a pre-eminently non-colonial power.

The theories of Russia's Asianness adapted certain traditional motifs of Tsarist monarchic ideology to the colonial context. The affirmation of the affinity between Russia and the East projected onto the politics of borders in Asia the principle of "voluntary submission" to power as a distinctive feature of Russia's difference from Europe. The idea of the subjects' spontaneous loyalty to the Tsar, developed under Nicholas I in opposition to the 1848 revolutions, was reframed in spatial terms and applied to the relationship between the Petersburg centre and the regions and peoples of the East. If the Russians were the heirs of the Golden Horde, to expand the state borders in Asia was to return home. In Ukhtomsky, for example, the theory of Mongol descent gave rise to the visionary project of a voluntary union between China and Russia, as related peoples, under the sceptre of the "white Tsar". In 1902 General Alekseyev cited similar arguments in the telegramme with which he recommended prolonging the occupation of Manchuria.

The Eurasian definition of Russia did not evolve into the notion of a civilisation surrounded by clear and accepted boundaries, whether national or multina- 
tional. The outer edge of this imagined cultural space remained open-ended and went well beyond the borders of the existing Imperial state. For the Pan-Slavist Lamansky the limits of the Russian world extended to much of eastern Europe, western Turkey and the Mediterranean coast of Syria. Uchtomsky thought that, proceeding beyond the Caspian and Lake Baikal, "we cannot find a clearly defined border ... beyond which our rightful land ceases to be". This indeterminacy produced very concrete effects in the years of the Tsarist crisis: defeat in the war with Japan in 1904, partly a result of the Asian destiny cultivated in the preceding decades, had repercussions on the political stability of the centre, contributing to the outbreak of the 1905 revolution.

\section{European Socialism, World Revolution and the Boundaries of Soviet Power}

The spread of Marxism from the 1880s onwards may be considered a temporary Europeanisation of Russian socialism. Leaders of the revolutionary movement such as Plekhanov compared the polemic between populists and Marxists to a continuation of the debate between Westernism and Slavophilism. Adopting Marxist categories as a science of revolution implied treating the difference between Russia and the rest of Europe as a case of the former lagging behind in a process interspersed with common stages. Pëtr Struve interpreted this approach as a kind of Europeanising pedagogy: "let us acknowledge our backwardness and go to the school of capitalism" (Critical Notes on the Economic Development of Russia, 1894). To accept the theoretical guidance of Marx and Engels was to recognise the cultural hegemony of German social democracy, adopt its party name (the Russian Social Democratic Workers' Party of Lenin and Martov) and adhere to the Second International. In this context, pre-Marxist socialism came to be termed "populism" (narodnichestvo), with the pejorative connotation of a Romantic, peasant, provincial socialism, lacking an adequate theoretical consciousness. In reality, during those years socialists of neo-populist inspiration such as Viktor Chernov were seeking their own way of relating to the European identity. They posited the social and geographical typology of a peasant periphery within Europe which included Russia as well as such countries as Hungary and Italy, thereby making it possible for the Russians to think of themselves as a type of Europeans.

However, the adoption of a "monistic" conception of history (like that of Plekhanov) did not solve the dilemma of proletarian revolution in a still predominantly agrarian country. How could one think of building socialism in a peasant 
world that orthodox Marxism classified as "petit-bourgeois", a conservative social category and therefore an inevitably retarded space in European history? Lenin solved the problem with an intellectual operation which was in many ways a mirror image of that of Chernov but which, unlike the latter's theory, emphasised Russia's primacy in the world, not just in Europe. Instead of differentiating the capitalist centre from its agrarian peripheries he associated the future of Russia with the two greatest examples of modernity in the early twentieth century, Germany and the United States - forms of development summed up in the concepts of a "Prussian path" and an "American path" towards revolution. Rather than the more indirect "Prussian path" (involving a capitalist evolution of noble estates and a proletarianisation of peasants) he preferred the "American path" - a revolutionary departure that would eliminate all feudal remnants and give access to the landed resources of the imperial space, transforming the "semi-Asiatic" peasant into a modern farmer and a protagonist of history.

The notes on Capitalism and Agriculture in the United States of America (1915) summarised the logic of this interpretation. American modernity represented "a model. Ahead of everyone. Freer than everyone, etc. [...] Compare America with Russia, if land were given to the peasants." Thanks to this identification with the "revolution of farmers", the peasant jacquerie became a component of the democratic-bourgeois revolution. More than that, the future potential of Russia could be associated with the ideal type of the most advanced agriculture of the time, developed in the wide, extra-European spaces of the prairies. Lenin was to some extent inspired by Karl Kautsky's Der amerikanische Arbeiter (a series of articles translated in seven Russian editions with the title The Russian Worker and the American Worker), where the leader of German social democracy dealt with the "enigma" of the difference between Europe and America discussed by Werner Sombart, in Warum gibt es in den Vereinigten Staaten keinen Sozialismus? (1905). Struck by the radical nature of the Russian revolution of 1905, Kautsky represented Russia and America as two incomplete mirrors of the European future, characterised respectively by revolutionary vigour and the highest degree of development of capitalist productive rationality. Lenin adopted the triangular comparison between Germany-Europe, the United States and Russia, but subtly modified it to delineate a historical destiny which emphasised the central significance of Russia. He imagined the socialist revolution in the Tsar's peasant empire as an acceleration of history which would make it possible to bring the two extra-European halves together, realising the primacy of socialism and modernity simultaneously: not only "the soviet”, then, but also "electrification", whose applications in the United States Lenin studied attentively.

The Bolshevik revolution was conceived in a worldwide perspective, rather than a European one. This influenced the representation of the future state and 
its geopolitical position, even before the creation of the Soviet Union. At the beginning of the First World War Lenin reflected on the future configuration of the states at the end of the conflict, taking into account the various revolutions which were then thought to be imminent or probable. He foresaw the dissolution of the empires of Austria, Germany and Russia, but refused to hypothesise, in place of them, the rise of a European federal republic, which would have entailed the sharing out of colonies in the rest of the world. Rather, he imagined the ultimate goal of a "United States of the world (not just of Europe)", preceded by a phase in which one or more socialist countries would clash with other countries which were still capitalist (On the Slogan for a United States of Europe, 1915).

The creation of the Soviet Union would link these representations of Russian centrality with the historical concreteness of a state, its diplomatic and military power as well as its borders. The Civil War (1918-1921) realised the reconquest of most of the post-Tsarist space, starting from the central nucleus of a territory not much larger than historical Muscovy and against the background of a very serious economic and social crisis and food shortages. The new Bolshevik elite succeeded in regaining control of the territory, except for the westernmost regions, defeating a series of alternative state-building projects of heterogeneous political types. In the peripheries that had eluded its control it encouraged, at various times, "proletarian" national insurrections and repressed hostile national movements, until in 1922 it took on the configuration of a federation of socialist republics, each with its own institutionalised borders but subject to the centralised hierarchy of the communist party.

The theory of "socialism in one country" acknowledged the failure of the hypothesis of post-war revolution in the major European countries and therefore the impossibility, at least in the immediate future, of a leading role for socialist Russia in a process of pan-European socialist construction. The change in direction imposed by Stalin from 1929 onwards was a response to the perception of the fragility, both internal and external, of a country which had emerged from the civil war suffering from the effects of significant economic regression. A state pursuing global ambitions had to cope with resources even more limited than those available to pre-revolutionary Russia. The collectivisation of the countryside and the Great Terror - the repression of real or potential dissident fifth columns - proceeded in parallel with accelerated industrialisation, pursued chiefly in preparation for another war. These were accompanied by the use of the communist international as an indirect tool of foreign policy, both in the European political context and in that of the anticolonial movements outside Europe. The dual prospect of a homeland of socialism and of a great power, associated more explicitly in the late 1930s with the patriotic symbols of Tsarist state greatness, was translated into the further expansion of state borders. 
Alliance with Nazi Germany in the years 1939-1941 made possible the annexation of some territories of the former Tsarist empire that had been lost in the course of the revolutionary crisis. The Soviet state acquired Bessarabia, which became the Soviet republic of Moldavia, and northern Bukovina, which was linked with socialist Ukraine, along with eastern Galicia and Volhynia. It absorbed eastern Poland, which was absorbed into Soviet Belorussia, and the Baltic republics of Lithuania, Latvia and Estonia. Only unexpected resistance in the Winter War (1939-1940) prevented Finland from coming completely within the Soviet sphere of influence, though it lost part of Carelia. With a few minor variations, these outer boundaries emerged unchanged at the end of the Second World War, during which the Soviet Union defeated, at a colossal human cost, the Third Reich's plan to conquer and unify Europe.

Even after 1945, however, the political limit of sovereignty maintained a multiple and elusive geometry, a continuing indeterminacy between "inside" and "outside", between what what was one's own and what was of others, which is a constant feature of centuries of Russian history. This ambiguity derived not only from Russia's historical position midway between Europe and Asia, but particularly from the ideology of a state which found its raison d'être in the ambition to play a hegemonic role on the world stage, and therefore beyond Europe and beyond Asia. The triumphant Soviet Union was a predominantly Russian state directed by a Georgian leader (Iosif Dzhugashvili), and united with the numerous Soviet peoples by the party's supra-national identity. Its official ideology was inspired by two German authors, Marx and Engels, the study of whose works had become compulsory in all schools, even in the remotest villages of Central Asia and the Far East. Despite this indisputably European inspiration, the Soviet Union aimed to represent a model for the many new states that had emerged from the process of decolonisation in Asia, Africa and Latin America, an alternative on a global scale to the declining European powers and the growing North American superpower.

It was not at all clear where the actual boundaries of power of this further variant of the "Russian state" lay. The internationalist ideology aroused loyalty in communist parties all over the world and so made it possible to influence the internal politics of other states. There was an internal and official frontier of the Russian Federal Republic (which in its turn comprised numerous autonomous national republics), and a further frontier which separated, in the west, the Soviet Union and the East European popular democracies. Beyond that was the "outer empire", the additional space of an indirect but very concrete sovereignty which extended as far as the physical and political wall of Berlin. Other borders delimited about forty urban areas within the territory of the Soviet Union according to the criteria of security and political loyalty, because of sensitive military or 
industrial installations. One of these "closed cities" was Sevastopol, a powerful symbol of Russian patriotism in its different historical declinations. Soviet citizens, including residents' relatives, could only enter by means of a procedure comparable to a visa application for a foreign country. In any case, there was no question of Europe having "westernised” Russia. On the contrary, the Russian state had extended its ideological, political and military power over almost half the European continent.

Translated from the Italian by Jonathan Hunt

\section{Bibliography}

Bassin, M 1991, "Russia between Europe and Asia: the Ideological Construction of Geographical Space”, Slavic Review, vol. 50, no.1, pp. 1-17.

Kappeler, A 2001, Russland als Vielvölkerreich. Entstehung, Geschichte, Zerfall, Beck, Munich. Laruelle, M 1999, L'idéologie eurasiste russe ou Comment penser l'empire, l'Harmattan, Paris-Montréal.

Masoero, A 2000, “La funzione dell'esempio americano in Herzen e Černyševskij” in Il pensiero sociale russo. Modelli stranieri e contesto nazionale, eds A Masoero \& A Venturi, F. Angeli, Milan, pp. 33-93.

Masoero, A 2013, “Territorial Colonization in Late Imperial Russia: Stages in the Development of a Concept”, Kritika: Explorations in Russian and Eurasian History, vol. 14, no. 1, pp. 59-91.

Rossiya i Vostok 2000, eds SM Ivanova \& BN Melnikhenko, Izd.vo S.-Peterburgskogo universiteta, St. Petersburg.

Schimmelpenninck van der Oye, D 2010, Russian Orientalism. Asia in the Russian Mind from Peter the Great to the Emigration, Yale University Press, New Haven.

Venturi, A 1997, “Russko-italyanskaya model V.M. Chernova (1899-1902)” in Russkaya emigratsiya do 1917 goda - laboratoriya liberalnoy i revolyutsionnoy mysli, Evropeysky Dom (Rossiyskaya Akademiya Nauk - Maison des sciences de l'homme), St. Petersburg, pp. 21-30.

Walicki, A 1973, Una utopia conservatrice. Storia degli slavofili, Einaudi, Turin.

Wortman, RS 1995, Scenarios of Power: Myth and Ceremony in Russian Monarchy, Princeton University Press, Princeton.

Zorin, A 2004, Kormya dvuglavogo orla. Literatura i gosudarstvennaya ideologiya $v$ Rossiy $v$ posledney treti XVIII - pervoy treti XIX veka, Novoe literaturnoe obozrenie, Moscow. 